Japanese Journal of Transfusion Medicine, Vol. 37. No. 5 37(5): 727-730, 1991

ラウンドテーブル・ディスカッション I

輸血部の現状と将来

司会 伊藤 和彦 (京都大学医学部附属病院輸血部)

柴田 洋一（虎の門病院輸血部）

1. 輸血部の現状と将来に関するアンケート調査結果について

\author{
伊 藤 和 彦 \\ 京都大学医学部附属病院輸血部
}

はじめに

今年の日本医学会総会のメインテーマは「転換期に 立つ医学々医療一創造と調和と信頼」である。日本医 学会の分科会の一つである日本輸血学会で「輸血部の 現状と将来」をラウンドテーブル・ディスカッション (RTD)のテーマとして取り上げたことは，時期を得た 適切な選択である。

輸血部が従来の検査主体の輸血学から, 治療業務を 取り込んだ輸血医学を領域とする部門に変換しつつあ ることは，世界的動向である，一方，日本の輸血事業 は, やっと血浆分画製剂の国内自給自足を実現するべ く始動した。この目標を達成するためには, 病院輸血 部の適切な対応が必要である.

日本の病院で輸血部の設置されているのは, 主とし て大学病院であり, これ以外の一般病院では極めて少 ない．多くの病院では輸血部の設置が重要な課題であ る。これには輸血部像が必要である。一方, 既設の輸 血部に拀いては, 将来の方向を探って, その entityを 確立すべく努力をしている。

RTD の資料作成のために「輸血部の現状と将来」に 関するアンケート調査を行った。その結果を報告する.

$$
\text { アンケート調査対象施設 }
$$

国立，公立括よび私立大学病院と一般病院の輸血部 の実務責任者, 輸血部のない病院では, 日本輸血学会 の評議員にアンケート調査の回答を依頼した。

輸血部の設置されている病院を正確に把握していな いが, 国立大学病院43中 33 , 私立大学病院 29 中 20 , 公 立大学病院 10 中 4 ,一般病院では 3 と推測する.

アンケート回収率は, 国立大学で $91 \%$, 公立大学で $70 \%$, 私立大学で $76 \%$, 一般病院で $69 \%$ であり, 全体 で $81 \%$ あ゙あた。予期した以上の良い回収率であり, 各病院が「輸血部の現状と将来」へ深い関心を寄せて いる現われと受け止めた。

$$
\text { アンケート調查方式 }
$$

質問は11項目から成り，病院輸血部の業務，体制， 教育, 日赤血液センターとの関係に関するものである. 研究についての直接の質問はない.

輸血部の将来の時期を, 現状の輸血部体制で迎える 明日からの「近い将来」と, 輸血部の抎充や体制の变 革を見込んだ「遠い将来」に分けた。質問事項に対し て, 現在実施しているか，近い将来または遠い将来に 実施計画があるかと問いかけて, 回答を依頼した。

アンケート調査は平成 2 年 12 月 1 日から平成 3 年 1 月15日までの期間で回答を依頼した。

\section{アンケート調查結果}

調査結果を表 1 , 表 2 に示す。学会会場で配布した 資料と同じである。

質問 1 「検査業務の導入」では, HLA 型検査は約半 数の施設で実施している. 血小板型検査の実施はより 少なく, 遺伝子工学的検査法はさらに少ない。各検査 の近い将来および遠い将来での導入計画をしている回 答が多い。

質問II「自己血輸血への関与」では，液状保存によ る眝血式が大学病院輸血部ではかなり普及している. 凍結保存方式は, 近い将来および遠い将来での採用計 画が多い，回収式，希䣋式を現在実施していると回答 した施設があるが，輸血部が直接どの程度関与してい るのか明らかでない。

質問III「骨髄移植への関与」では，同種または自己 骨髄の採取と処理, 凍結保存に関与している施設が国 立, 私立大学で約 $1 / 3$ あ. 全体では近い将来に実施計 画している回答が多い.「治療全般への関与」は, 輸血 部単独で行っている施設もあるかもしれないが，大部 分は診療科に出向いて参加していると推測される。

質問IV「へムアフェレーシス治療および体外血液処 理法への関与」では, プラスマフェレーシスとサイト 
表 1 第39回日本輸血学会総会ラウンドテーブル・ディスカッション「輸血部の現状と将来」に関するアンケート調査結果

現：現在実施

近：現体制下の近い将来実施予定

遠：体制変革後の遠い将来実施予定

\begin{tabular}{|c|c|c|c|c|c|c|c|c|c|c|c|c|c|c|}
\hline \multicolumn{2}{|c|}{ 国立大学 $39 / 43$} & \multicolumn{2}{|c|}{ 公立大学 $7 / 10$} & \multicolumn{2}{|c|}{ 私立大学 $22 / 29$} & \multicolumn{2}{|c|}{ 一般病院 $11 / 16$} & \multicolumn{3}{|c|}{ 合計 $79 / 98$} \\
\hline 現 & 近 & 遠 & 現 & 近 & 遠 & 現 & 近 & 遠 & 現 & 近 & 遠 & 現 & 近 & 遠 \\
\hline
\end{tabular}

I . 検査業務の導入

\begin{tabular}{|l|r|r|r|r|r|r|r|r|r|r|r|r|r|r|r|}
\hline 1. HLA 型検查 & 19 & 10 & 6 & 2 & 3 & 2 & 14 & 2 & 5 & 5 & 1 & 4 & 40 & 16 & 17 \\
\hline 2. 血小板型検査 & 4 & 14 & 15 & 1 & 3 & 1 & 5 & 10 & 5 & 1 & 3 & 4 & 11 & 30 & 25 \\
\hline 3. 遺伝子工学的検査法 & 2 & 13 & 18 & & 3 & 4 & 2 & 8 & 10 & & 2 & 5 & 4 & 26 & 37 \\
\hline 4. その他 & & & & & & & & & & & & & & & \\
\hline
\end{tabular}

II. 自己血輸血への関与

\begin{tabular}{|l|r|r|r|r|r|r|r|r|r|r|r|r|r|r|r|}
\hline 1. 貯血式：採血と液状血液保管 & 29 & 10 & 1 & 6 & 1 & & 20 & 2 & & 6 & 2 & 2 & 61 & 15 & 3 \\
\hline 2. " : : 採血と涷結血液保管 & 7 & 13 & 14 & 1 & 1 & 4 & 6 & 6 & 3 & 2 & 1 & 4 & 16 & 21 & 25 \\
\hline 3. 回収式：手術室内業務 & 12 & 5 & 7 & 2 & & 3 & 9 & 3 & 1 & 4 & & 2 & 27 & 8 & 13 \\
\hline 4. 希釈式：手術前採血 & 9 & 8 & 6 & 1 & & 3 & 4 & 6 & 1 & 4 & & 2 & 18 & 14 & 12 \\
\hline
\end{tabular}

III. 骨髄移植への関与

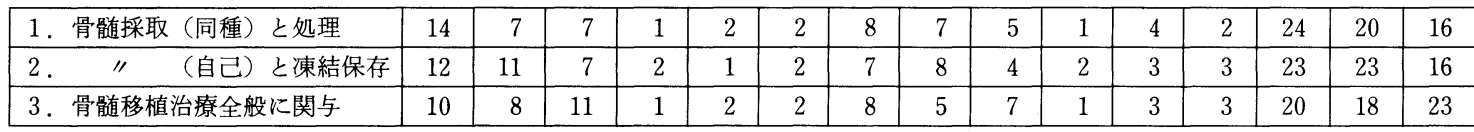

IV. ヘムアフェレーシス治療拈よび体外血液処理療法への関与

\begin{tabular}{|l|r|r|r|r|r|r|r|r|r|r|r|r|r|r|r|}
\hline 1. プラスマフェレーシス治療 & 19 & 5 & 4 & 5 & & 1 & 18 & 1 & 1 & 7 & & 1 & 49 & 6 & 7 \\
\hline 2. サイトアフェレーシス治療 & 19 & 5 & 7 & 2 & 1 & 2 & 18 & 1 & 1 & 6 & 3 & 1 & 45 & 10 & 11 \\
\hline 3. LAK 療法 & 12 & 1 & 12 & 1 & & 3 & 2 & 8 & 6 & 2 & 2 & 3 & 17 & 11 & 24 \\
\hline 4. 体外循環光化学療法 & 1 & 5 & 14 & & 1 & 2 & 1 & 4 & 9 & & 1 & 3 & 2 & 11 & 28 \\
\hline 5. 末梢血幹細胞採取と凍結保存 & 11 & 14 & 7 & 2 & & 3 & 7 & 8 & 5 & 3 & 2 & 3 & 23 & 24 & 18 \\
\hline 6. その他 & & & & & & & & & & & & & & & \\
\hline
\end{tabular}

V. GVHD 予防のための血液放射線照射

\begin{tabular}{|l|r|r|r|r|r|r|r|r|r|r|r|r|r|r|r|}
\hline 1. 実施する & 20 & 12 & 5 & 4 & & 2 & 14 & 5 & 3 & 4 & 2 & 2 & 42 & 19 & 12 \\
\hline $\begin{array}{l}\text { 2. 血液センターで実施 } \\
\text { するのを待つ }\end{array}$ & 1 & 4 & 3 & & 1 & 1 & & 2 & 2 & 1 & & 1 & 2 & 7 & 7 \\
\hline 3 . 実施の必要性はない & & & & & & & 1 & & & & & & 1 & & \\
\hline
\end{tabular}

IV. 院内採血

\begin{tabular}{|l|r|r|r|r|r|r|r|r|r|r|r|r|r|r|r|}
\hline 1. 実施する & 15 & & & 3 & 1 & & 14 & & & 10 & & & 42 & 1 & \\
\hline 2. 止める & 6 & 5 & 6 & 1 & & 1 & 4 & 3 & 2 & & 2 & 1 & 11 & 10 & 10 \\
\hline 3. 成分採血だけ行う & 11 & 6 & 3 & 2 & 2 & & 4 & 4 & & 6 & & 2 & 23 & 12 & 5 \\
\hline
\end{tabular}

VII. 日直・当直体制の導入

\begin{tabular}{|l|l|l|l|l|l|l|l|l|l|l|l|l|l|l|l|}
\hline 1. 休日の日直業務 & 8 & 2 & 19 & 4 & 1 & & 10 & 6 & 4 & 2 & 3 & 3 & 24 & 12 & 26 \\
\hline 2. 当直業務 & 7 & 3 & 18 & 4 & 1 & & 8 & 5 & 7 & 2 & 3 & 3 & 21 & 12 & 28 \\
\hline
\end{tabular}

VIII. 教育について

\begin{tabular}{|l|r|r|r|r|r|r|r|r|r|r|r|r|r|r|r|}
\hline 1. ポリクリまたは実習の導入 & 22 & 8 & 7 & 6 & 1 & & 14 & 6 & 1 & & 1 & 1 & 42 & 16 & 9 \\
\hline 2. 卒後教育の体系的確立 & 4 & 21 & 9 & 2 & 3 & 1 & 1 & 16 & 4 & 3 & 4 & 1 & 10 & 44 & 15 \\
\hline
\end{tabular}

X. 輸血部体制の拡充と变革

\begin{tabular}{|l|l|l|l|l|l|l|l|l|l|l|l|l|l|l|l|}
\hline 1. 現体制の払充でよい & & & 13 & & & 1 & & & 4 & & & 4 & & & 22 \\
\hline 2. 変革すべきである & & & 23 & & & 5 & & & 17 & & & 5 & & & 50 \\
\hline
\end{tabular}

XI. 日赤血液センターとの関係

\begin{tabular}{|l|r|r|r|r|r|r|r|r|r|r|r|r|r|r|r|}
\hline 1. 現状でよい & 8 & 1 & 1 & 1 & & & 3 & 1 & & 5 & 1 & & 17 & 3 & 1 \\
\hline 2. 業務の交流を盛んに行う & 10 & 10 & 2 & 3 & 4 & & 7 & 7 & 4 & 2 & 5 & & 22 & 35 & 6 \\
\hline $\begin{array}{l}3 . \text { 体制を一体化する(兼務・ } \\
\text { 兼職を進めて) }\end{array}$ & & 7 & 5 & & 1 & 2 & & 3 & 5 & & 2 & & & 13 & 12 \\
\hline
\end{tabular}


表 2
IX，新しい業務の導入
1. 遺伝子治療
2. 輸血を不必要にする研究
3. 外来輸血クリニック
4. 主治医の実技指導
5. 成分輸血療法の確立
6. 輸血症例の追跡調査
7. 習慣性流産の治療
8. MSBOS, T \& Screen
9. 移植片の保存(皮ふ, 骨, 骨髄など) $\rightarrow$ tissue bank
10. 移植免疫の検査 $(?)$
11. In Vitro 培養幹細胞の供給
12. 臟器移植の輸血学の確立
13. 藏器移植のデーター管理
14. 精子・卵子の保存
15. 抗白血球抗体の検査
16. Flow cytometry 細胞自動解析
17. 白血球細胞表面抗原検査
18. Adaptive immunotherapy
19. 院内血液製剂の調整
20.フィブロネクチン，X而因子の製剂化
21. 血漿分画製剂の使用管理
22. 認定医カリキュラム掲載事項

XI. 日赤血液センターとの関係
1. 人的交流
2. 研究面の協力体制
3. 大学内に日赤センター採血所設置
4. 血液の診療科への直配と保管
5. 血液センターに輸血医学の “指導医”を配置
6. 適格な人材の所長就任
7. 血液センターの体質改善と実力アップ
8. 血液センターの輸血効果・副作用などの情報収集の促進

アフェレーシス治療を実施している施設が多い.「末梢 血幹細胞採取と凍結保存」は約 $1 / 4$ 施設で実施されてお り, 将来での導入計画がある. LAK 療法は遠い将来で の施設計画が多い.

質問 V「GVHD 予防のための血液放射線照射」では, 実施している回答が約半数で，近い将来での実施計画 が多い. 血液センターでの照射を希望する回答が少数 あったこのアンケート調査では，血液照射する対象 患者の内訳は不明である。

質問VI「院内採血」では，全血採血を実施している 回答が約半数あり，成分採血は約 $1 / 3$ である。しかし， 全血採血は将来的には止める方針と受け止められる。 成分採血は近い将来での実施計画がある.

質問VII「日直・当直体制の導入」では，実施施設が 1/3弱である. 私立大学での実施比率が高い. 業務内容
X. 輸血部体制の変革

I 、輸血部の拡充に近い変革

1. 講座制

2. 職員の増員・充実 教官：専門医師, 優秀な医師 技官：専門技官

3. 研究のできる部門作り (現業務の削减)

4. 技官：検査を減らし，患者に密着した輸血業務を行う

5. 診療科の輸血関連業務を取り込む

6. タテ割りからョコ割り業務体制の拡大

7. 各輸血部は独自の特色を出す(臨床血液, 臨床腫瘍学, 移植免疫など)

8. 輸血部の独立(国立病院)

9. 他部門との交流強化：中検, 診療科, 免疫学部門

II. 輸血部の転換

1. 中央診療部門・講座制：検査部門の強化

2. 診療科：移植，治療を行5

3. 移植センター

4. 造血幹細胞移植部: 診療科的部門

5. 血液細胞治療部門

III. 輸血部と他部門との併合, 再分割

1. 他部門と併合する。

中検と併合

ICU, CCU .と併合(検查業務は中検へ) $\rightarrow$ 血液治療部門

検査は中検へ，血液供給は血液センターへ $\rightarrow$ 診療治療部門

血清検査室, 麻酔科と併合

血清検査部門と併合

血液, 感染症, 免疫との併合統一
は調査していない。現体制では実施困難であるとの回 答が約 $1 / 3$ あ。

質問VIII「教育について」では，ポリクリまたは実習 を導入している施設が約半数ある。卒後教育の体系的 確立は近い将来での実施計画が多い。

質問IX「他の新しい業務の導入」では, 表 2 に示す ように，検査に関するもの $(8,10,15 \sim 17)$, 臓器移 植に関するもの $(9 ， 11 \sim 14)$, 診療に密接に関係する もの $(3 \sim 7,18)$ ，血浆分画製剂の管理，製剤化に関 するもの $(19 \sim 21)$, 輸血に代わる治療の開発研究に関 するもの $(1,2)$ などに分類される.

質問 $\mathrm{X}$ 「輸血部体制の拡充と変革」では，現体制の 拡充でよいとする回答は少なく，変革すべきであると の回答が多い、特に公立，私立大学で顕著である。輸 血の変革内容について寄せられた意見を，I．輸血部 
の拡充に近い変革, II．輸血部の転換, III．輸血部と 他部門との併合，再分割，に大別して表 2 に示した. 多彩な意見が出された。

質問 XI「日赤血液センターとの関係」では, 輸血部 と血液センターとの業務交流を盛んに行いたいとする 回答が多く, 将来像として体制の一体化を望む回答も あった．他の意見としては，表 2 に示すように，血液 センターに要望する事項であった。

\section{考 察}

冒頭に述べたように本アンケート調査は，RTDの 資料として利用することを目的に実施したので，この 調査結果から結論を出すことよりも，これを土台にし て活発で有意義なディスカッションを交わすことを望 みたい。

本アンヶートでは, 国立, 公立, 私立大学と一般病 院に分けて結果を集計したが，輸血部の人的体制はそ れぞれの系列内で一応でなく,大きな格差がある.従っ て, 輸血部職員数の多少で, 輸血部を分類して, 結果 を集計した方が，結果をよく理解できたと思われる。

職員数の多い一部の輸血部を除いた大多数の輸血部 の現状の悩みは職員の不足である，赤血球関連の輸血 検査以外の本アンケートにある業務の現在の実施状況 が低いのは人的余力がないことによると推測される。
従って，各項目にわたって遠い将来での採用計画が多 い. 本年 4 月から国立大学病院では週40時間勤務制が 試行されて，土，日躍日の輸血部業務は休業状態にな る.質問VIIの回答で見られるょらに, $2 / 3$ 施設では遠 い将来でなければ, 日直, 当直業務を実施できない状 態である。

大学病院での業務は, 診療, 教育, 研究である。輸 血医学教育も 1 人の教官では, ポリクリ, 実習は実施 困難である.診療科での教育は卒後教育に重点がある。 輸血医学に関しては, 卒後教育の体制が整っていない。 本アンケート調査では, 研究に関する質問は省略し た. 輸血医学に関する研究は大学病院輸血部が当然担 当すべきである. 研究の方向についてはディスカッ ションの対象として十分討論すべきことであるが，現 状の研究体制は貧弱である. 今後の日本の輸血医学の 発展を促すためには研究体制の強化が必要である.

大部分の一般病院で輸血部が設置されていないた め, 輸血過誤の発生する危険をはらんでいる.アンケー ト回答の中に, 輸血部設置を熱望する意見が奇せられ たことを最後に記したい。

謝辞：アンケート調査にご協力いただいた多数の方に感 謝を申し上げます。本論文をもって結果の報告と致します。 


\title{
2. 一般病院輸血部の立場から
}

\author{
柴 田洋一 \\ 虎の門病院輸血部
}

\section{はじめに}

一般病院の輸血部は診療に直結した業務でいかに患 者の診断や治療に貢献できるかが，その存在意義の有 無を左右する。この点は, 大学病院輸血部がもつ診療・ 教育・研究の三つの役割とはその立場が異なっている.

我々の病院輸血部ではこの 5 年間に大きく業務内容 の変化が生じた．本稿ではこの変化の背景と今後の病 院輸血部について考察した.

（1）輸血療法に対する考方方の変化（輸血療法の再 検討）1991年にエイズといら疾病が明らかになり, 又 この死に至る疾病が輸血を介して伝染することが知ら れるようになった。 この時を契機として, 以下に述べ る副作用について認識が深まった。

(1) エイズ, 肝炎及び未知の感染症：これらすべてを 事前検査で完全に check することは不可能である.

(2) 輸血後 GVHD：本邦では心臟外科手術患者で 660例に 1 例 GVHD が発症していることが明らかと なっている. 今後, 高齢者の手術が益々増加すると, 様々な外科手術患者で GVHD が発症することが予測 される。

(3) 免疫抑制作用：手術時に輸血を使用した癌患者 では, 癌の再発率が高いとの報告がなされている。血 友病患者では繰り返し，第 8 因子製剤の投与を受けて いると, エイズの感染の有無にかかわらず免疫機能異 常の状態にあるといわれ, 他人の血液成分中には, 免 疫機能を抑制する物質が含まれていることが示唆され ている。八木田ら ${ }^{11}$ はマウスでの輸血実験で皮下に植 えられた腫瘍が同種血輸血の場合は, 自己血輸血の場 合の 2 倍の増殖を示したと報告している. 免度抑制作 用をひきおこす物質は不明であるが，考えてみれば同 種血輸血の場合, 赤血球型, 白血球型, 血小板型, 血 浆型の異なる血液が入ってくるが，患者はこの異物を 主として免疫機構を動員して排除するのである。この 作業は相当に免疫系に負荷のかかることではないかと 想像される．従って，繰り返し輸血を受けた患者では 免疫機構が疲弊し, 機能低下を招来すると思われる。

以上，続々と明らかになる輸血の副作用を考慮する と今日, 同種血輸血を実施することは救命を意味する。
つまり輸血は一種の藏器移植なのであり, 臟器移植と 同一レベルの問題を抱えていることが深く認識される に至った。

（2）今後の輸血部

このように輸血療法に対する考え方の大きな变化に 伴って病院輸血部の役割も大きく変化しつつある. 同 種血輸血の適応が厳しくなるにつれ, 従来の業務（輸 血用血液の保存・管理, 安全な輸血の為の諸検査など） は縮小傾向にあり, 代って以下の新しい業務が必要に なってきた（図1参照）。

(1) 緊急体制：輸血療法が救命としての目的が明確 になり，また近い将来の職員の週休 2 日制の実施は夜 間，休日の輸血部の緊急体制の整備が重要となってい る.

(2) 自己血輸血：手術に際しての輸血を,どの程度ま で自己血輸血で肩代わりできるかは, 輸血部にとって 当面の最重要課題であろう. 自己血輸血は非常に安全 で有効である．更にェリスロポイェチンが使用可能に なれば短期間に貯血が可能となる。 今後, 各病院は,

図 1 輸血部の将来

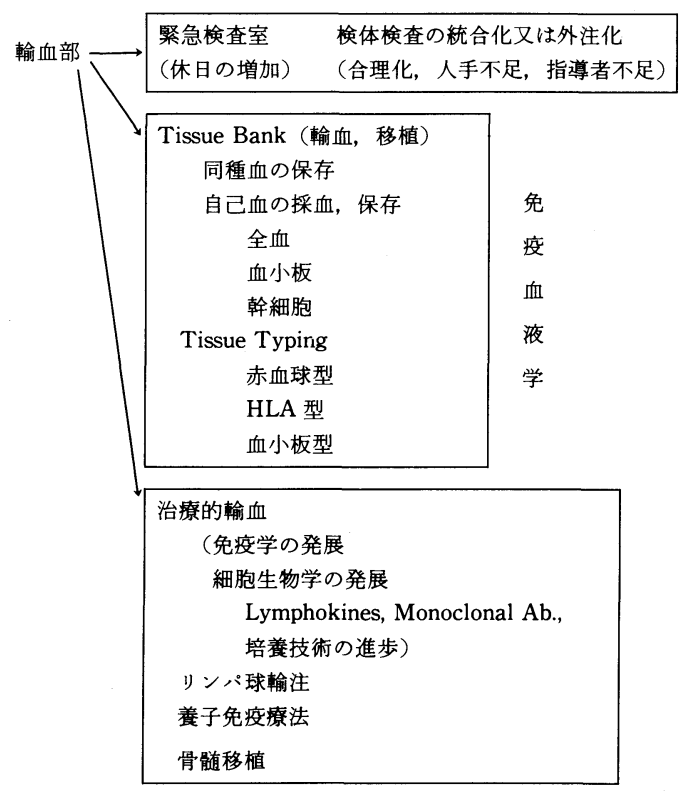


外科系各科ごとの手術時の，全輸血に占める自己血輸 血の割合を算出し，努力目標を設定するような試みが なされてゆくと思われる。

(3) Tissue Bank としての業務：輸血部は将来 Tissue Bank として変身をとげてゆくだろう。これから発 展する分野で，かつ輸血部が深く関与すると思われる ものを列挙する。

1） LAK，TIL，2）骨䯣細胞の分離・凍結，3）臟器 移植に伴う Tissue Typing (HLA) など.

$$
\text { おわりに }
$$

以上のべたように病院輸血部は急速に変貌を遂げて
ゆくだろう，病院経営の悪化や人手不足は検体検査の 合理化，外注化を急速に促進している点も見逃せない。 しかし，診療各科や検査部では出来ない上記の様な業 務は今後ますます重要であり，そこに病院輸血部の存 在意義があると考光ている。

\section{文献}

1）八木田旭邦, 竹内教能 : 特集. 輸血子臨床. 輸血飞 よる腫瘍增殖促進作用. カレントテラピー, $7(7)$ : $77-81,1989$. 
Japanese Journal of Transfusion Medicine, Vol. 37. No. 5 37(5) : 733-736, 1991

\title{
3. 国立大学の立場から見た輸血部の現状と将来
}

\author{
品田章二 \\ 新潟大学医学部輸血部
}

はじめに

輸血部を必要とする理由に, 交差試験済の適合血を 供給してもら劣るからと感じる医師が多い，少なくと も約15年前, 演者も血液内科に席を置いた頃，そうで あった。

輸血部へ移籍した当初は, 赤血球型と抗体の検出方 法や，抗体と反応しない赤血球型抗原の頻度などを， 確かな知識を持つ古参の検査技師から教えてもらい, 口写しで臨床の医師に伝授した。いわゆる, 雇われマ ダムであった。しばらくして医師や看護婦への情報伝 達は, 検查技師より良く通じていることに気付いた。 輸血部の医師はインターフェイスでもあった。

21年前, 信州大学が当番校となって全国国立大学附 属病院輸血部会議が開始された。以来，大学もちまわ りで, 毎年, 国立大学の輸血部の抱光る諸問題につい て, 討論が重衫られている，国会開催の時期と重なる と, 文部省高等教育課は欠席し勝ちになるものの, こ の会議の特色として, 文部省扮よび中央血液センター からの参加がある。

本稿の前半は, 平成 2 年の秋, 三重の津市で開催さ れた会場で配布されたアンケートの結果に基づき，国 立大学の輸血部の現状を検討し, 後半は著者の所属す る新潟大学医学部附属病院輸血部の経験と私見記述 する。

\section{現状と考案}

A. 全国国立大学附属病院輸血部の状況

名古屋大輸血部のアンケート集計を簡易ソフトで棒 グラフに変換して以下に示した.

1. 輸血部の認可の有無と病床数

平成 3 年 4 月現在, 国立 43 病院中, 33 校に輸血部が 認可されて扮り, 未認可は, 模様無しの棒で示す 10 校 である(図 1 ).

認可申請のタイミングにより, 各年度に認可される 大学数には多少の変動もあったが, 病床数には左右さ れなかった。早期に認可を得るために, 未認可大学内 で意見統一し，申請順位を一位にする努力も不可欠で あろら。

2. 名大学輸血部に専属する職員構成
輸血部が未認可の大学を除さ, 平成 2 年度の集計で は，教官数は $1 \sim 6$, 技師数は $2 \sim 8$ 名と差異はある ものの, 必須要員であった。 しかし, 看護婦や事務官 は $0 \sim 2$ や $0 \sim 4$ 名と, 配置しない大学も散見された (図 2 ).

各大学での人員配置は, 各輸血部の歷史を物語るが, 専属職員が 4 名では, 単なる輸血検査部門に終わる可 能性が大きい。

3. 日赤から購入した全血製剤の単位数

大学により, 年間2,000未満, 4,000未満, 6,000未満 および 1 万 5,000 単位と多様であった（図 3 ）。

昨今の逼迫した血液事業を円滑に運用するために, 全血使用を減少させることも輸血部の大切な業務であ

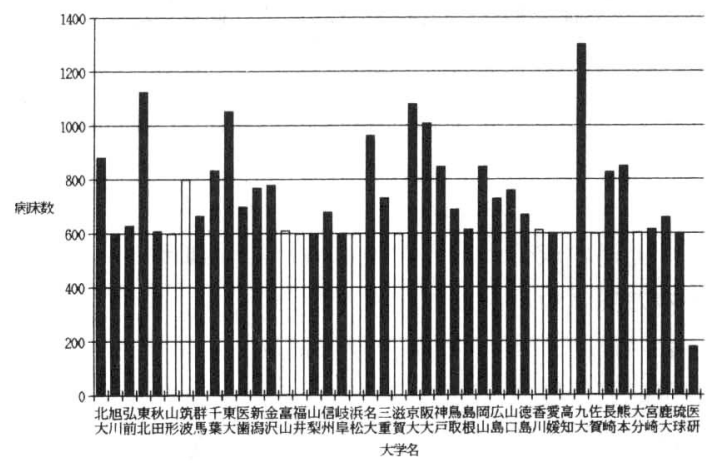

図 1 国立大学病院の病床数と輸血部認可. 1991年 4 月

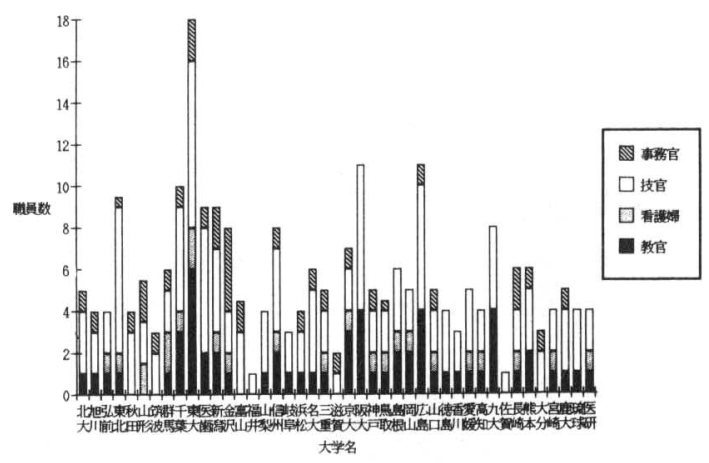

図 2 輸血部専属の職員数の内訳. 1990年 9 月 


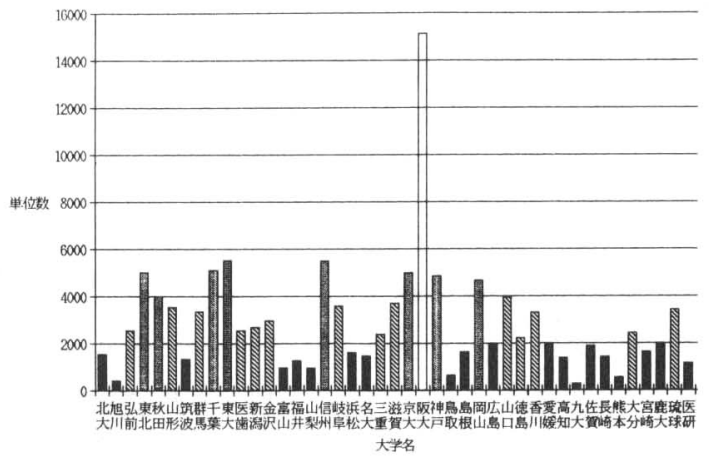

困 3 日赤から購入した全血製剤。1989年度

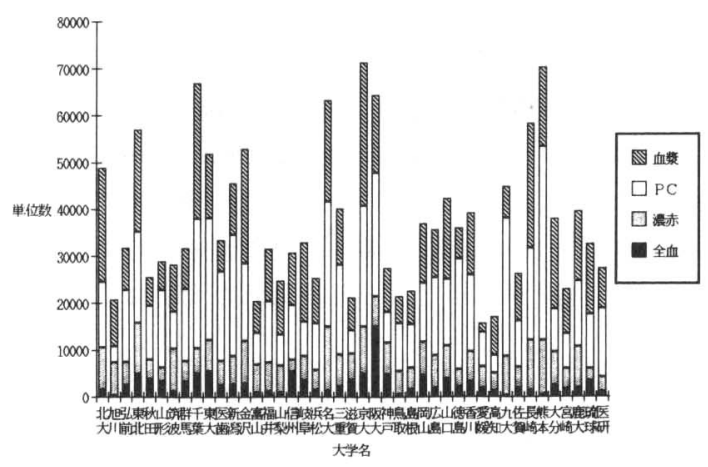

図 4 日赤から購入した各種製剤の単位数. 1989年度

る。上述の成績は, 各大学に抢ける輸血部と臨床各科 との力関係を反映した結果であろう。

4. 各種日赤製剂の購入単位構成

平成元年度は, 各大学に㨟いて, 全血に比べ, 血小 板や，血浆の単位数の多いことが示された。また各大 学により，各製剂の構成比率も区々であった（図 4).

近年の血浆製剂や血小板製剂の使用数の急増が正し い適応に基つくく，否かの判断と修正指導に果たす輸 血部の役割は大きい.

5. 輸血部の赤血球系検査総数

$\mathrm{ABO}$ 型検査，不規則抗体スクリーニング，クロス マッチの件数と比率を見ても，各大学で大きく異なっ ていた（図 5 ).

各大学に拈ける輸血部の考光方や技師数の充足程度 により, 赤血球系検查件数構成にも，大きな差異が生 ずることが示された。

6. 貯血式自己血輸血

平成 2 年 4 月に貯血式自己血輸血が保険医療として 認めら机たので，今後予定手術に際し，患者血液の冷

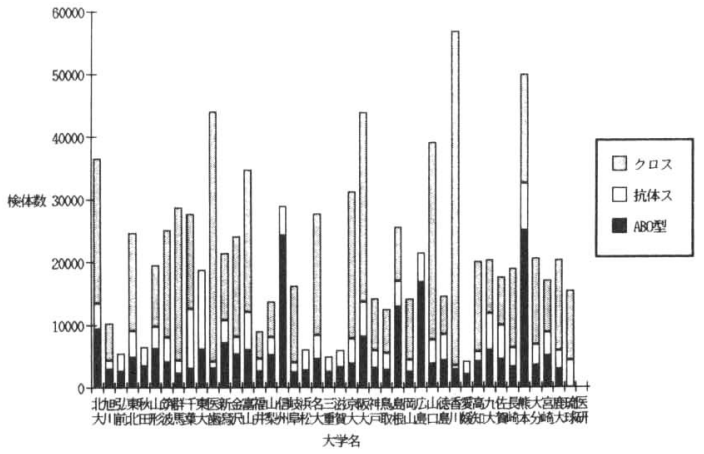

図 5 赤血球系の各種検査件数の内訳. 1989年度

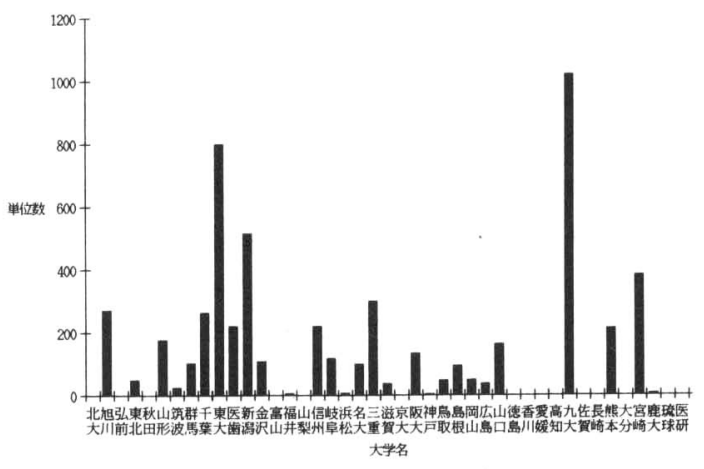

困 6 自己血液状保存の単位 $(200 \mathrm{~m} l$ 換算 $)$ 数. 1989 年度

蔵庫保存が多くなると予想される。アンケートへの回 答によれば, 保険收載前の平成元年度でも，1,000単位 以上の血液保存を行った大学も西った（図 6).

検查部的性格加脱皮し, 新しい輸血医療対応す るために，輸血部の看護婦を配置することも極めて重 要と考える。

\section{小括}

以上は，アンケートに答党る立場からいうと，必ず しも同じ認識レベルで答えているとは限らない。いわ ば，アンケート・ラッシュを来たしている今日，おな じソフトプログラムを用いて, 回答基準を揃光, 輸血 部に最低必要な基本業務項目を決めることが，今後進 むべき輸血部の将来を見通すためにも, 急務であろう。

B. 新潟大学医学部輸血部の状況

昭和 43 年に輸血部が予算措置されて以来，数の変動 も西ったが，院内措置などにより，教官 2 , 看護婦 2 その後 1 , 技師 4 , 事務 2 , 合計 9 名が輸血部に専属 している. 
1. 院内 (輸血部) での全血採血状況

発足以来, 院内採血続けているが，その内容は変 化した。昭和60年頃まで, 年間約 1,500 単位あった全血 採血が，以後急激に減少した（図 7 ).

しかし, 採血室ベッドは成分採血, 養子免疫用リン 八゙球採取抒よび自己血採血で占められ, 看護婦の配置 は不可欠な状況にある。

2. 院内の濃厚血小板血浆の採取数

各年度別に示したが，昭和56年をピークに，バッグ 法による採取は次第に減少, 代りにアフェレーシス・ ボールを用いる PC 採取が増加した（図 8).

一時廊下に湓れる供血者で賑わいをみせた輸血部前 が閑散としているので, 外部からは暇な部局と思われ がちである、そこで，看護部に看護婦の配置を説得し 続けている。なぜなら,ベッドにいる人は針で熬がっ て和り, 長時間, 注意深い観察が必要であり, 無事で あるのが当たり前, 事故があったら, 大変な事態に陥 るからである。

自動成分採血装置は, 中央施設としての輸血部に設

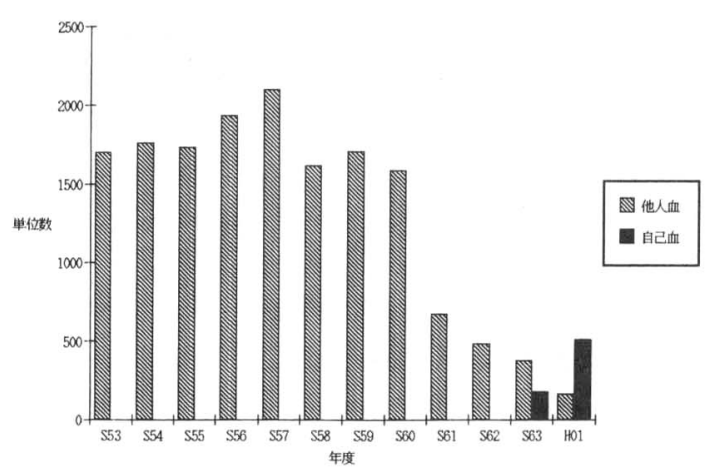

図 7 新潟大学の院内採血 ( $200 \mathrm{~m} l$ 換算) 数. 1990年 3 月

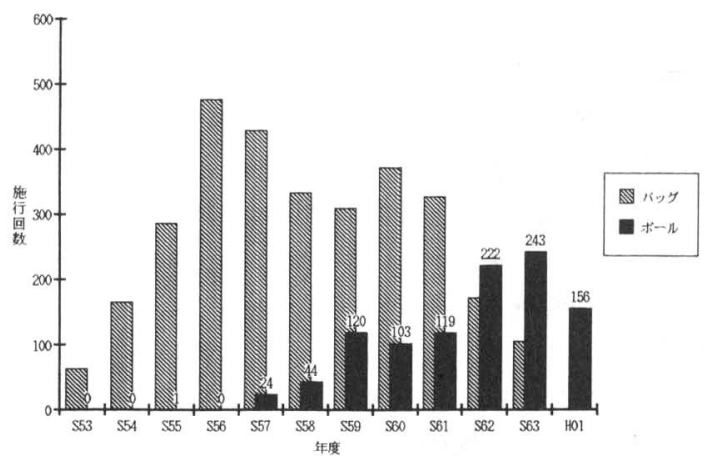

図 8 新潟大学の院内 $\mathrm{PC}$ 採取回数. 1990年 3 月
置し, 輸血部に健康人抢よび患者を集め, 事故なく採 血されるように運用すべきであろう。

3. 日赤から購入した PC 単位数

バッグ法による血小板製剤 PC が頭打になり, 平成 元年から，アフェレーシス法（図中ボール法）による PC が顔を司覗かせた（図 9）。

大学輸血部に抢いて自動成分採血装置に関する技術 開発と安全性確認に関する検討がなされ，その後に， 血液センターが業務を引き継ぐことになった経緯が示 されている。

4. 院内の顆粒球成分採取

患者の白血球数が 1,000 以下になると, 臨床医は, 顆 粒球成分を発注するが, 輸血部では経過観察を勧める ことが多い，事実その後，白血球数も正常化すること が多い.

一時期輸血部を忙しくしてくれた顆粒球採取は昭和 59年にピークとなったが，予防的輸血を抑壳たことも あって, 以後激減した（図10）。

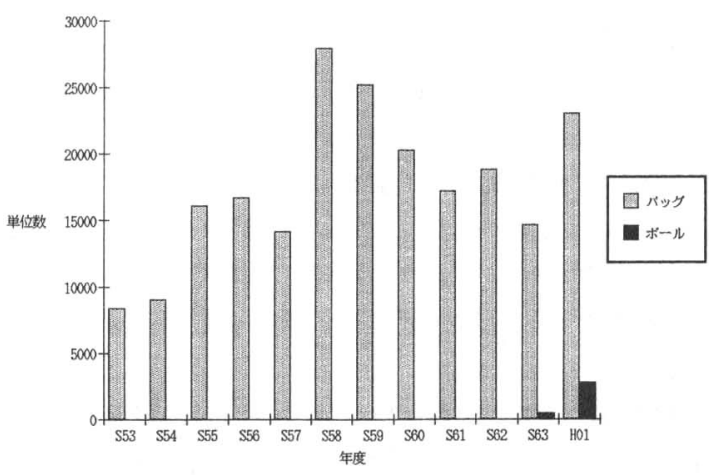

図 9 新潟大学が使用した日赤 PCの単位数.1990年 3 月

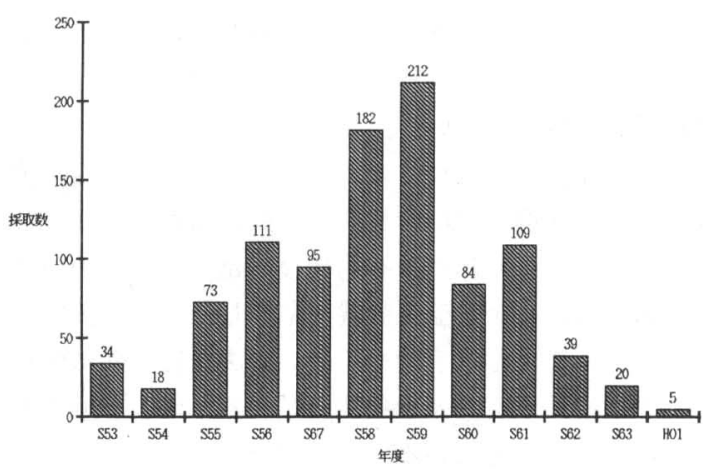

図10 新潟大学の院内顆粒球採取回数。1990年 3 月 


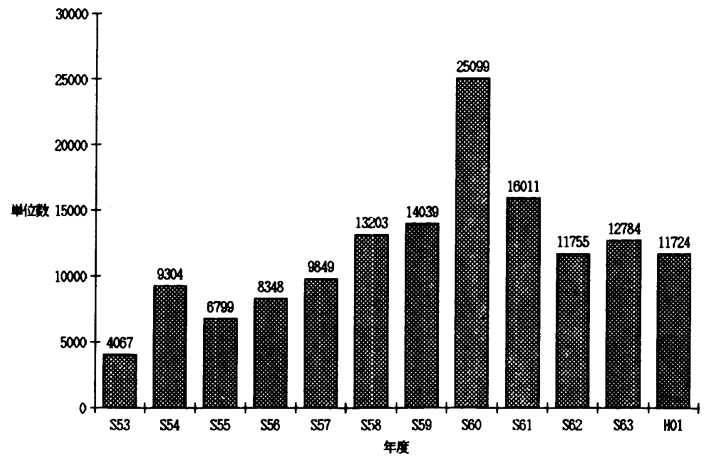

図11 新潟大学の使用した日赤 FFP.1990年 3 月

適切な輸血医学とくに，成分の適応に関する輸血部 の適切な指示が, 如何に重要であるかを物語っている.

\section{5. 教育と実習}

毎年， 6 月に，研修医，指導医，および看護婦を対 象として，輸血部ガイダンスを行い，各科の血液の使 い方を説明し，適正使用について説明している。すな わち，卒後の教育は輸血部の大きな仕事である。

新潟大学に拈ける日赤からの血浆の使われ方の年次 推移を示す（図11）.

とくに平成 2 年度には，抗血友病因子製剂を作成す るために血奨が使われるので, 極端に節約を呼び掛け, 主治医への便りなどで了解を取り付けている.

著者は『人員不足の現状では, 緊急時の交差適合試 験は，医師がやれるように訓練しておくべき』と考古 る。そのために，輸血部には日当直を置かない方針で ある.

夜間に行ら交差適合試験は新しい医員, 研修医の仕 事になるが，いざ一人で行うとなると，不安になる。 そのため，主治医用のテーブルに，実習に用いた説明 書を置き，それを頼りに実施できるように設営してい る.

ただし，試薬の置場や簡単なことが判らない場合に 備えて, 輸血部医師はポケット・ベルを所持し，夜間 や休祭日に対応している。

平成 3 年度から, 全ての血液をセンターが直接配達 する方式に变換したのを契機に, 血液備蓄庫を設置し たが，帳簿の付け忘れや不適切な行為をする医師の呼 びだし用に，ビデオ監視装置を準備した。この機器の 設置はあくまでも, 手助や正しい方法を短時間に伝達 する手段に用いることを条件とし，各医局の了解をと りつけ，協力を得ている。
表 1 輸血部の方向 (1991年 4 月)

\begin{tabular}{|c|c|}
\hline \multicolumn{2}{|c|}{ 部内：業務に埋没しないこと } \\
\hline & $\begin{array}{l}\text { a. 基本業務の数量化と統一整理 } \\
\text { b. 新技術の開発と導入 }\end{array}$ \\
\hline \multicolumn{2}{|c|}{ 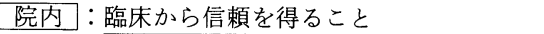 } \\
\hline \multirow{3}{*}{\multicolumn{2}{|c|}{$\begin{array}{r}\text { a. 臨床科との相互の情報交換 } \\
\text { b. 医師, 技師, 看護婦の研修 } \\
\text { 日赤 } \quad \text { ：人的交流で協調の確立 }\end{array}$}} \\
\hline & \\
\hline & \\
\hline \multirow{2}{*}{\multicolumn{2}{|c|}{$\begin{array}{l}\mathrm{a} . \text { 血液センターへ研修医の派遣 } \\
\mathrm{b} . \text { 共同研究の推進 }\end{array}$}} \\
\hline & \\
\hline \multicolumn{2}{|c|}{ 官庁：移植医療への転換 } \\
\hline & a ．中央施設として講座の設置 \\
\hline & b. 大中の各病院に輸血部を設置 \\
\hline
\end{tabular}

将来にむけて

今後, 輸血部の取るべき方向をまとめてみた(表 1). すなわち，以下の 4 点である.

1. 輸血部内では，業務に埋没しないこと，そのため に，少なくとも基本業務を同一基準で数量化し，整理 し，残りを新技術の開発と導入のために，費やすこと.

2. 院内にあたっては，各臨床科から信頼を得るこ と, そのために, 臨床科と相互の密接な情報交換を行 らこと，そのために，一定期間を医師，技師，看護婦 の研修に充てること.

3、日赤との関連は重要であり, 人的拉よび物的交流 で協調の確立をはかる。具体的には血液センターへ研 修医の派遺による, 血液事業の体得, 輸血に関する共 同研究の推進.

4. 最も大切なことに，監督官庁への働さ掛けがあ る. 移植医療時代への転換期と捕え, 輸血部を中央施 設として認識してもららこと，早急に講座の設置を認 可してもららこと, さらに，大学だけでなく，大中の 各病院に輸血部を設置することなど.

付 記

投稿する時点で, 発表後の討論内容を振り返ってみ たい，日赤センターが輸血部業務を代行するので，大 学輸血部は不要との突出した意見も出た。しかし, 各 県のセンターの力量が均一でないのは, 国立大学の輸 血部の現状と類似しており，極論であろう。

私見であるが，大学輸血部は教育機関に所属するこ とを認識する，その上で，輸血部は，（1）輸血医療の 現状を免許所持者（医師）へ逐一教示する標識的役割 を果たすこと，(2) 輸血医療に関する新しい技術開発 を行って，血液センターへ検討済の安全確実な業務を 引き渡す，指導的部局と位置づけたい。 


\section{4. 私立大学輸血部の立場から}

原 宏
兵庫医科大学輸血部

1.はじめに

一般に私立大学（私学）の輸血部は国公立大学に比 較して恵まれた条件にあると思われている，果たして そらであろらか。私学には独特の校風・伝統があり， それぞれ独自の教育目標を持っている，従って，輸血 部をとりかこむ環境もそれぞれ異なるものと思われ る。そこで, 私学輸血部の現状の把握を輸血部教員の 定員の有無・検査項目・その他の業務等について, ア ンヶート調査を行らとともに将来どのように方向を目 指しているかに検討を加えた。

\section{2. アンケート調查の成績}

医学部のある私学・29校にアンケートを郵送し， 24 大学の輸血部あるいは輸血関連検査の責任者から返送 して頂いた。この中には，私学に入るとはいえ，自治 医科大学・産業医科大学のように国立に近い経営が行 われている私学も含まれている。

(1) 輸血部に有無

返事を頂いた 24 校中 4 校には輸血部はなく，中央検 查部の中にある輸血室あるいは血清検査室で検査が行 われ，血液製剤の保管・管理は薬剤部で行われている 施設もある。

（2）輸血部教員について

輸血部のない施設において，教員定員が確保されて いないのは勿論である。しかし，輸血部の設置された 大学においても10施設（50\%）には輸血部固有の定員 枠はなく，兼任の教員のみの施設が50\%ある。一方， 教授以下 5 名の教員, 2 名の研修医の定員が確保され ている施設もあり，千差万別が現状である。私学の輸 血部の大学間の差異は教員定員に端的に現れる。従っ て, 私学では大学の輸血部に対する考方方は教員定員 に反映されている。

(3) 技師数について

各輸血部の検査技師数は $3 \sim 13$ 名（平均7.0名）であ り, 輸血部のない施設で輸血検査に $3 \sim 5$ 名(平均 4.3 名）の技師は確保されている，従って，輸血するに必 要な最低限度の検査である血液型・交差適合試験を行 らに必要な技師数は確保されていると思われる。

（4）教育について

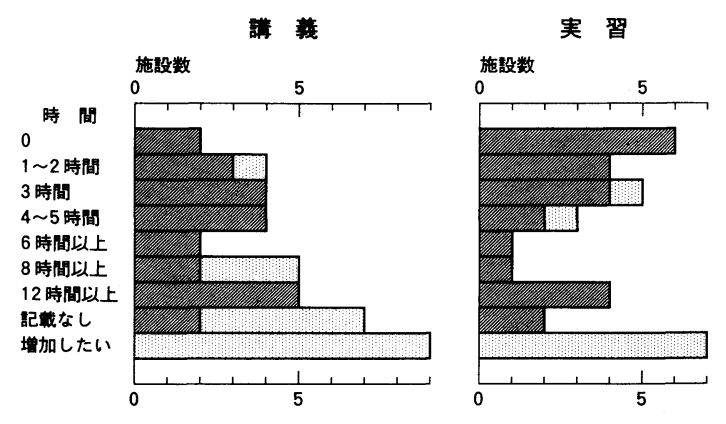

図 1 私立大学医学部輸血部の現状と将来 ש：現在している施設。网：将来したい施設. 記載 なし：講義時間数の記載なし。

輸血学の卆前教育に関しては図 1 に示した。講義の 方を見ると輸血部は全く講義に関与していない施設 (2/20) から 12 時間以上 $(5 / 24)$ かけている施設まであ る. しかし，講義時間数を増やして欲しい施設 $(9 / 24)$ が多い。

実習の方を見ると全く実習に関与していない施設が 6 施設と多く, 多くの施設 $(14 / 24)$ が 3 時間以下の実 習しかしていない，その割には実習時間を増加したい との施設は少ない $(7 / 24)$.

（5）検査について

血液製剂の在庫管理は必要かつ安全な輸血には欠か せない，従って，輸血部のない施設においても在庫管 理は行われている。しかし，血液製剤の保管は輸血部 のない一施設において薬剤部が管理している。

検査項目として, 血液型・交差適合試験・抗体スク リーニングについては輸血部の有無にかかわらず行わ れており，輸血には欠かせない検査であることを示し ている(図 2 参照). しかし，ATLA 抗体・HIV 抗体・ $\mathrm{HBs}$ 抗原 $\cdot \mathrm{HBs}$ 抗体・ $\mathrm{HBc}$ 抗体 $\cdot \mathrm{HC}$ 抗体・梅毒血清 反応等は輸血部以外で実施している施設も多い，従っ て, 院内採血を行っている施設では輸血部に拈いて供 血者の選択を総合的にチェックできるシステムを作っ ておく必要がある。

その他の検査項目を見ると図 3 に示すように HLA 関連検査項目として, HLA 型判定 $(13 / 20,65 \%)$ ・ 


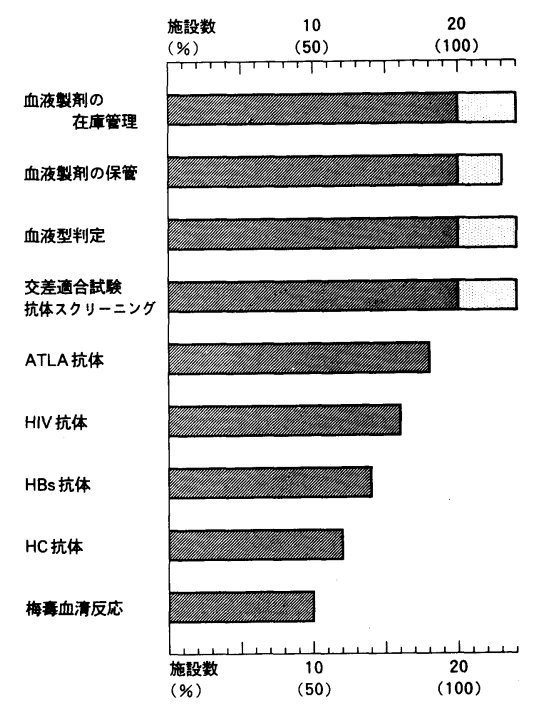

図 2 私立大学輸血部の現状. 日常検査 『：輸血部のある施設. 『图：輸血部のない施設.

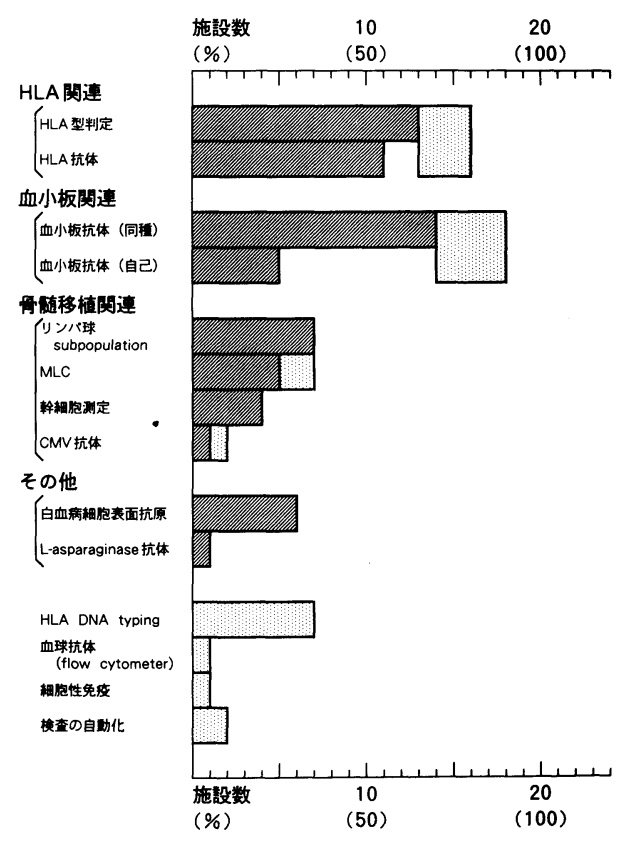

図 3 私立大学輸血部の現状. その他の検査 ש：現在行っている施設. 将来行いたい施設.

HLA 抗体 $(12 / 20,60 \%)$, 血小板関連検査項目として 同種血小板抗体 $(14 / 20,70 \%)$ ，血小板自己抗体（5/ $20,25 \%)$, 骨䯣移植関連検査項目としてリンパ球 subpopulation の解析 $(7 / 20,35 \%)$, リンパ球混合培 養 (MLC), 幹細胞測定 (4/20, 20\%), CMV 抗体 (1)
20, 0.5\%) 等が行われている.

（6）その他の業務について

前述の検査以外に, 白血球除去フィルターの在庫管 理, 輸血後 GVHD 予防のための放射線照射の他, 図 4 に示すように骨髄移植関連業務 $(10 / 20,50 \%) \cdot$ 自己

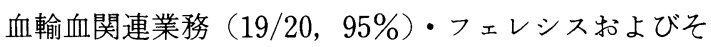
の技術を応用発展させた LAK 療法あるいは末梢血幹 細胞の採取を行っている施設が多い(17/20，85\%). これ等の業務の多くは専任・兼任を問わず，医師が直 接関与していると考学られる。それにもかかわらず, これら業務を実施したいと希望している施設を入れる と大半の施設がその中にいる.

\section{3.「アンケート結果」の考察}

病院における輸血部の存在意義は主治医に代って, 組織として，「必要時に適正でより安全な輸血」を行え るように保証することにある. 勿論, 輸血部が大学の 組織である以上，卒前教育を担当する義務がある.

輸血部のない施設では主治医が患者および供血者の 選択, 血液製剂の選択, 白血球除去フィルタ一の使用, 血液製剂の照射等に個人として対処し，責任をもって

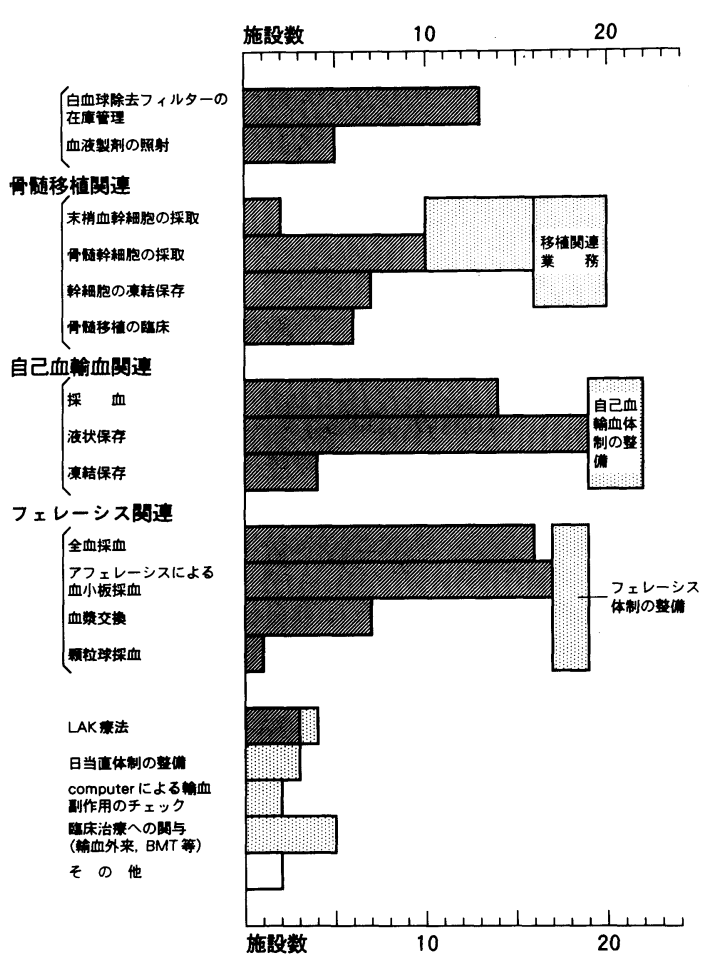

図 4 私立大学輸血部の現状と将来. その他の業務

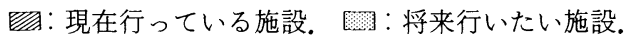


いる、一方，輸血部のある施設では，これらに対して 輸血部のある施設では組織の一環である輸血部が血液 型・交差適合試験をはじめとして血液製剤（供血者） および患者データをはじめとして, 輸血の安全性確保 に必要な検査を行い, データの一元管理を行って, 輸 血の安全性確保に努力している.

これらの大学の輸血部門を代表して，人に由来する 血液製剂を充分に臨床に役立てるために輸血をとりま く医学の進歩, 献血者確保のためにも社会との適合に 努力する必要がある. 輸血部が血液型・交差適合試験・ 抗体スクリーニング等の検査のみを行ら組織でないこ とを考学ると専任教員の確保は急務を要するものと思 われる。

このような輸血部の役割を考えると輸血学を一環し て教育する卒前教育を輸血部が担当し, 充実すること は急務を要することと思われる。しかし，各私学が独 自の教育方針・校風を持つことは当然であり，画一的 なカリキュラムを設定し, 強要するには問題がある。 それよりも輸血関連事項を医師国試に取り入れ, 輸血 の必要性・安全性・社会との適合等を具体的な課題を 通じて，国試受験者のみならず，社会全体に訴える姿 勢が重要と考えられる。このような姿勢を欠いている 現状を見ると文部省・厚生省の責任は重大である.

輸血部の現場で働いている人が考えている輸血部の 将来像はどのようなものであろら，輸血に関連する感 染症・免疫抑制・輸血後 GVHD 等の弊害を完全に克服 することは至難の技であろう，基本的には同種血輸血 を減少さす方向に向わざるを得ない，従って，自己血 輸血，エリスロポエチン等の造血因子の in vivo投与 等の同種血輸血を減少させる努力が今後も続けられる であろら、既に自己血輸血は大半の施設で行われ，今 後もその比重が増すものと思われる. その結果, 血液 型・交差適合試験・抗体スクリーニングおよび感染症 伝播の予防に要する検査の頻度は減少すると予想され る.

一方，多くの施設では HLA 関連検査および骨髄移 植関連業務に関与している，我が国においても骨髄移 植・腎移植のみならず, 心・心肺・肝・膵等の藏器移 植が定着するのはそれ程遠い将来とは思えない.その 際, 提供された貴重な臓器を有効に利用し, 拒絶反応 および移植後の GVHDを減らすにはHLA の血清学 的な型判定のみならず class II 抗原を DNA 型判定に より,より詳細に一致させることが重要と考えている 人も少なくない.この際, 患者と臓器提供者の選択に
輸血部が大きな役割を果たしたいと考えている人は多 い(HLA の DNA typing 希望 (7/20，35\%)). その 他, 個体識別の可能な遺伝子あるいは CMV 遺伝子を PCR 法を用いて骨髄移植後の拒絶反応・CMV による 間質性肺炎の早期診断を行いたいと希望している施設 もある。

'図 4 より, 造血幹細胞移植に関与する医師の多いこ とは推定される。血小板あるいは顆粒球採取で培った アフェレーシス技術を応用して，末梢血幹細胞を採取 して保存することも輸血部にとって，比較的容易な手 法と云い得る. 各大学によって条件は異なるものの, 幹細胞移植の臨床面まで関与し，その成果を確認する 施設も現れるものと思われる.同じように, アフェレー シス技術を応用して，LAK 療法に関与する施設もあ る.

同種血輸血を減少さすことが輸血部の重要な使命の 一つであるとすれば,

（1）自己血輸血の適応を拡大する(造血因子の利用, 血液保存方法の開発とその臨床応用).

(2) 臓器移植, とりわけ骨髄移植に関係する検查方 法・保存方法・造血幹細胞の培養法の開発とその臨床 応用

（3）アフェレーシス技術と他の技術を融合せて臨床 に応用する (末梢血幹細胞の採取と保存, LAK 等) の 技術を輸血部に蓄積し，臨床に寄与することが重要で ある).

アンケートから察するに輸血部教員は既にこれ等の

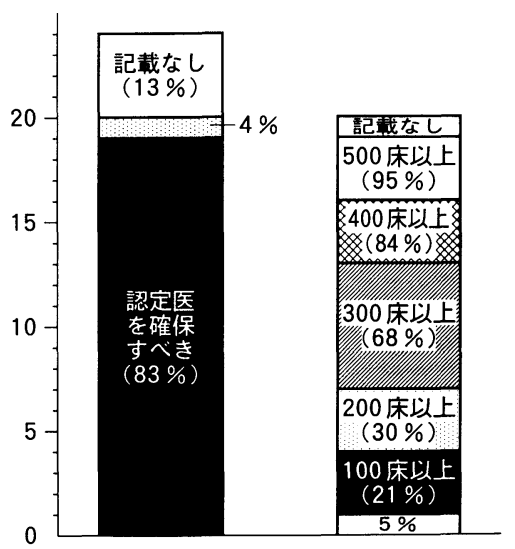

図 5 輸血学認定医制度について 一般病院においても輸血学認定医を確保すべきか否か (左側)（留どちらともいえない)，確保するとすれば どの位の規模の病院では確保すべきか（右側). 
点を意識して行動していることが分る，一方，輸血部 にこれらの技術を蓄積するには輸血部職員の大半を占 める検査技師が HLA の DNA typing, PCR 技術等に 習熟するとともに血液・幹細胞の凍結保存・末梢血幹 細胞の採取括よび幹細胞の培養測定・LAK の培養誘 導等に直接関与し, 輸血工学士とも呼ぶべき技術集団 が生まれることを期待している。

これからの輸血部は「同種血輸血の減少」を一つの 目標として，医師である教員にリードされつつ，各大 学毎に特色のある high technologyを蓄積した組織と して発展しつつあるものと期待している.

一方, 私学輸血部の教員は, 本年度に発足すること が決定された輸血学認定医制に大きな関心を持ち，自 からの identityをここに求めようとしている. 輸血学 認定医を取得しょうとする医師は私学の65\%（15/24） の施設にいるが，将来のことになると取得希望医のい る施設は僅か $29 \%$ （7/24）に過ぎず，49\%施設では不
明である。

一方，輸血部教員の $95 \%(19 / 20)$ は図 5 に示したよ 5に一般病院に打いても輸血学認定医を確保すべきと 考えている。しかし，どのような規模の一般病院が輸 血学認定医を確保すべきかについてはいまだ意見の集 約は困難のようである。「輸血の安全性と社会性の確 保」は単に大学輸血部のみならず一般病院においても 求められるべきものと私学の輸血部教員は考えている ことを現している.

現在, 輸血学会で論議されている輸血学認定技師の 問題とも関連するが「輸血の安全性と社会性の確保の ために」輸血学会として輸血学認定医を大学病院・血 液センターのみならず一般病院にも確保する必要性を 社会に訴えるように私学教員は望んでいる.

輸血のみならず移植に関連する技術を蓄積し，輸血 学認定の医師・技師として社会に認められれば輸血部 関係者の努力は報われたと考えられる。 
5. 血液センターの立場から：病院輸血部への将来的要望

\author{
清 川 博 之 \\ 福岡県赤十字血液センター
}

はじめに

我が国の医療機関に設置されている輸血部は，輸血 用血液の採血から検査, 製剤分離, 保存・管理, 出庫 までをミ二血液センタ一的に行っている欧米の院内 Blood Bank とは同一に論じられない面もある。

血液センター側からみた理想的な輸血部像について は，そのセンターの置かれた医療環境によって多少異 なると考えられるが, 基本は, user(臨床医)-collector （血液センター） relationshipを円滑にするコーディ ネーターとしての役割を期待していると言って良い。 安全な輸血が適正に行われるための方策として，医療 機関に抽血液製剂の検査・管理システムの充実, 臨床輸血に関する医学教育の徹底などの必要性が言わ れてきた。 とくに血液製剂の適正使用が行われるため には，健全で良好な user-collector relationship が作 られなければならない。そのためには，両者の果たす べきそれぞれの役割を改めて認識し連携を深める必要 がある。

\section{血液センターの役割と輸血部の役割}

血液センターの主な役割は，いうまでもなく輸血を 必要とする医療機関と献血者の間にあって，出来る限 り安全で有効な良質の血液を確保し，医療機関からの 要求に応じて供給することである，緊急であることを 理由に安全性を無視した院内採血が安易に行われてき た背景には, 血液センターの対応も問題とされるが, 血液センターから出庫される血液製剤は GMP（医薬 品の製造管理および品質管理に関する基準）で厳しく 品質管理が行われていると言うことが臨床医には意外 と知られていない事も理由の一つとしてあげられよ う。特に1989年 6 月に厚生省から出された「輸血療法 の適正化に関するガイドライン」では，院内採血の供 血者にも血液センターで行われている検査項目と全く 同じものを実施することを要求されており，適正輸血 のみならず輸血用血液の安全性を確保することがうた われている。このよらな状況下で，行われた産業医 大輸血部の自己血採血以外の院内採血廃止宣言 ${ }^{11}$ は, これからの輸血部の役割を明確にしていこうとする姿 勢の現われであると受け止めている。図 1 には血液セ

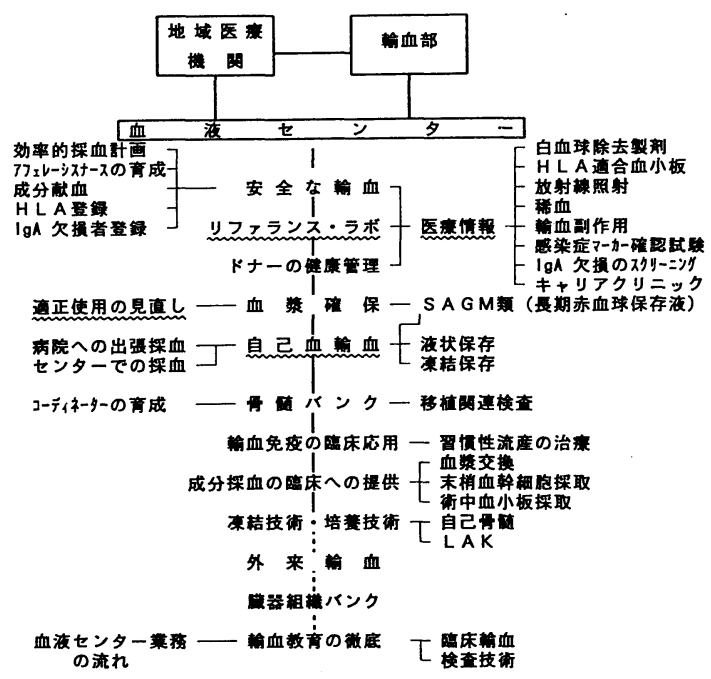

図 1 血液センターの役割

ンターの持つ機能を生かしたこれからの役割を列挙し ているが, 外来輸血, 臓器組織バンク以外のものにつ いては共同研究などの形で福岡センターで既に実施さ れている，骨髄移植など移植医療の分野が急展開する 中で臨床科とより近い距離にある輸血部での機能の再 編成はこれからの血液センターの在り方にも大きく影 響を与えることは必至である。

\section{血液製剤の需給システム}

病院の中での輸血部の置かれた立場は血液製剤の使 用状況（図 2 ）からも推測することができる。 A， B, C, D 大学病院のベッド数はそれぞれ $1,200,1,300$, 800，600である。1986年 8 月血液製剤の適正使用ガイ ドライン施行後より着実に使用量が减少しているのは 全科をコントロール出来る輸血部のある $\mathrm{D}$ 大学病院 で, 輸血部に専任医師のいない A 大学病院では逆に使 用量が増加傾向を示している．福岡センターでは血液 の有効利用の一助として血液バッグのラベルに有効期 限のバーコードをいれているが，血液製剤の需給をよ りスムーズに行らためには将来輸血部とコンピュータ のオンライン化が必要であると考えている(図 3,4 ). 


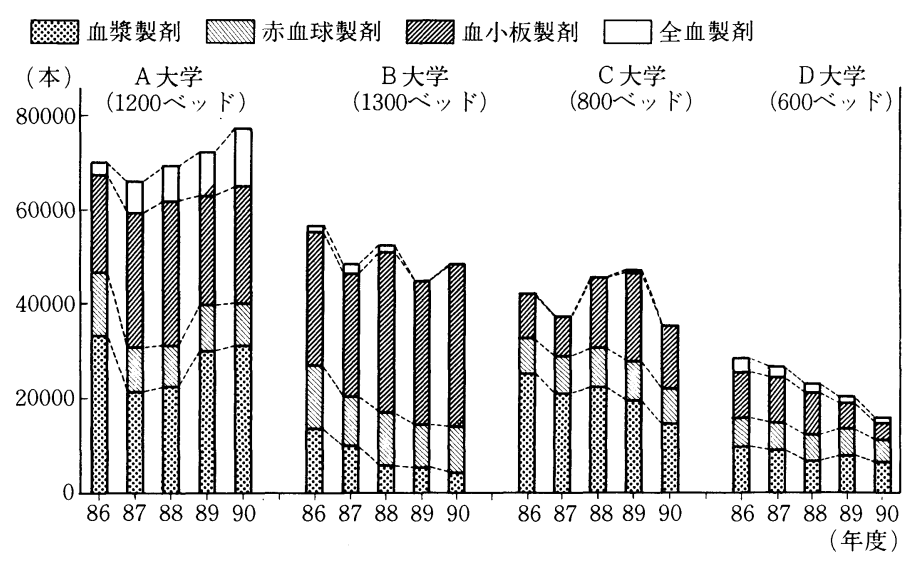

図 2 大学病院における血液製剤使用状況

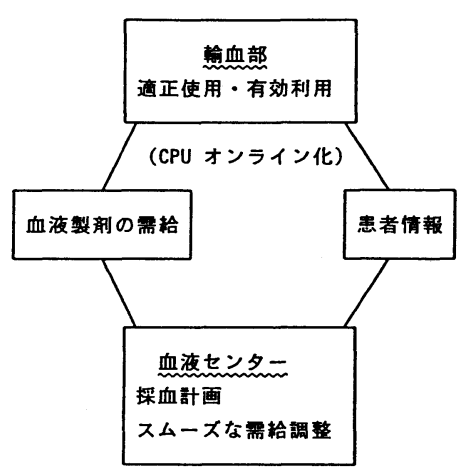

図 3 血液の需給システム

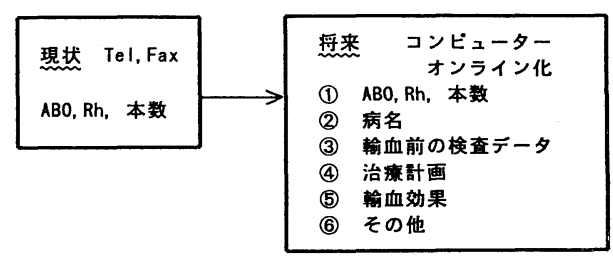

図 4 患者情報

\section{自己血の管理システム}

1983年以来, 福岡センターと医療機関（主として大 学病院の整形外科, 心臓外科) との共同研究として央 施してきた自己血輸血も, 現在 SAGM 類(赤血球長期 保存液）を使用して冷凍保存から液状保存へと転換を 計っている. 自己血の管理状況に関しては福岡セン ターから医療機関に報告しており, 手術 1 週間と手術 前日にはセンターから確認の連絡を入れている。輸血 部とコンピュータのオンライン化が実現すれば, 安全 で確実な自己血の管理が行えるものと期待される.
リファランス・ラボラトリ

当血液センターで全医療機関に向けておこなってい る輸血副作用に対する医療情報システムの利用状況に ついてみると, 必ずしも輸血部のある疾療機関から輸 血副作用の精查依頼が多いと言らわけではない（輸血 部の有る医療機関からの依頼 $14 \%$ ). 輸血副作用の原因 検索は安全かつ有効な輸血につながることを考える と, 輸血部における情報収集のシステム化が待たれる 所である。

\section{先端医療への係わり}

この数年来, 自己血輸血や骨髄移植などに関心が高 まると共に，血液センターと医療機関との関係は非常 に複雑になってきており, 臨床との交流は輸血部を通 してだけのものではなくなってきている，骨髄バンク など欧米の血液センターのように先端医療を支えるた めの多面的機能を持つ医療チームの一員へと変身を迫 られている日本の血液センターも, これからの輸血部 の機能の持ち方に大きく影響されると考えられる.

\section{輸血の教育}

輸血の教育についても議論されて久しい. 福岡セン ターでは将来ューザーとなる医学生の教育を重視し, 1987年 4 月より福岡大学医学部 5 年生全員の臨床実習 を受け入れている。輸血検査が出来ないような医療機 関でも輸血が行われている現状は依然として放置され ており，輸血認定医は血液センターにこそ必要である と考えられ，認定医制の教育カリキュラムについても 輸血部と血液センターで役割分担することが望まれ る.

$$
\text { おわりに }
$$

輸血部の動向は血液センターの将来展望と無関係で 
は無い、輸血医療において輸血部と血液センターは車 の両輪であり, 医療の現場が求めるものを的確にとら えて準備して行くことができるかどらかは，輸血部と 血液センターとの relationship によって決まると言っ
ても過言ではないであろう。

\section{文献}

1）䉆海久美子, 田中真典, 平野聡子, 他：院内採血の 現況報告. 日輸血会誌, 36(3)：474-478, 1990. 